\title{
A Devastating Cause of Burns: Synthetic Cannabinoid Abuse
}

\section{Yanıkların Yıkıcı Bir Nedeni: Sentetik Kannabinoid Suistimali}

\author{
Berrak Karatan ${ }^{1 *}$, Kamil Yamak ${ }^{2}$ \\ ${ }^{1}$ İzmir Bakırçay Üniversitesi Tıp Fakültesi, Çiğli Eğitim ve Araştırma Hastanesi, İzmir, Türkiye, \\ ${ }^{2}$ İzmir Sağlık Bilimleri Üniversitesi Tıp Fakültesi, Bozyaka Eğitim ve Araştırma Hastanesi, İzmir, Türkiye
}

e-mail: berrak222@hotmail.com, kamilyamak@hotmail.com

Orcid: 0000-0003-3921-5087

Orcid: 0000-0003-3784-4760

*Sorumlu Yazar / Corresponding Author: Berrak Karatan

Gönderim Tarihi / Received: 02.06.2021

Kabul Tarihi / Accepted: 24.06.2021

DOI: $10.34087 /$ cbusbed. 946900

\section{$\ddot{O} z$}

Giriş ve Amaç: Sentetik kannabinoidler, kannabinoid reseptörlerinin agonistleri olan insan yapımı kimyasallardır. Küresel olarak, 2000'lerden beri psikoaktif etkileri nedeniyle yasa dışı olarak pazarlanmaktadır. Türkiye'de ilk sentetik kannabinoid trafiği 2010'ların başında tespit edilmiştir. O zamandan beri, psikiyatrik ve bedensel komplikasyonları büyüyen bir endișe haline gelmiştir. Ülkemizde yaygın bir sentetik kannabinoid türü olan Bonzai, depresyondan öforiye kadar çeşitli zihin değiştirici etkilere sahiptir. Bu değişen zihin durumu, kullanıcıları travmaya yatkın hale getirmektedir. Bu çalışmada, Bonzai ile ilişkili yanık vakaları ile ilgili deneyimlerimizi sunduk.

Gereç ve Yötemler: Ocak 2018 - Aralık 2020 tarihleri arasında Plastik Cerrahi ile Ortopedi ve Travmatoloji kliniklerine toplam 12 hasta Bonzai ilişkili yanık nedeniyle sevk edildi.

Bulgular: Hastaların yaşları 18 ile 57 arasında değişmekte idi (ortalama yaş: 33,5 yıl). Toplam yanık yüzey alanı $\% 2$ ile \%40 arasında idi. Beş hasta yanık nedeniyle ameliyat edildi; bu hastaların hepsinde komplikasyon gelişti ve hastalar ikincil ameliyatlar geçirdi. İki hasta hastaneye kabul edildikten sonra vefat etti, üç hasta ise taburculuk sonrası takibe gelmedi. Hastaneden taburcu olduktan sonra sadece bir hastanın uyuşturucudan arınmış olduğu doğruland1.

Sonuç: Bu çalışmada, her yaştan ve her kesimden insanı etkileyebilen bu sentetik ilacın endişe verici tehlikesine dikkat çekmeyi amaçliyoruz.

Anahtar Kelimeler: Bağımlılık, Bonzai, İlaç, Rekonstrüktif Cerrahi, Travma.

\section{Abstract}

Objective: Synthetic cannabinoids are human-made chemicals that are agonists of cannabinoid receptors. Globally, they have been marketed illegally for their psychoactive effects since the 2000s. The first synthetic cannabinoid traffic in Turkey was detected in the early 2010s. Since then, their psychiatric and psychological complications have become a growing concern. Bonzai, a common form of synthetic cannabinoid in our country, has varying mind-altering effects, from depression to euphoria. This altered state of mind makes users prone to trauma. Herein, we present our experiences of Bonzai-related burn cases.

Materials and Methods: A total of 12 patients were referred to the Plastic Surgery, Orthopedics, and Traumatology Clinics between January 2018 and December 2020.

Results: Their ages ranged from 18 to 57 years (average age: 33.5 years). The total burn surface area ranged from $2 \%$ to $40 \%$. Five patients had been operated on due to burn injuries; all of these patients had complications and secondary surgeries. Two patients were lost after admission to the hospital, and three patients were lost during follow-up. Only one patient was verified to be clean from drugs after discharge from the hospital.

Conclusions: We aim to point out the alarming danger of this synthetic drug, which can affect all ages and walks of life. 
Keywords: Addic, Bonzai, Drug, Reconstructive surgery, Trauma.

\begin{abstract}
1.Introduction
Addictive substance abuse is increasing in the world and has become a global problem. This alarming increase in substance abuse leads to increases in drug-related trauma incidents. Alcohol and drug abuse-related burn injuries are well known in the literature [1-5]. Drug abuse has been shown to raise the risk of being involved in major trauma, such as burns. Additionally, drug abuse and alcohol use increase the length of stay in the hospital, complications, and mortality in burn patients $[1,6$, 7].
\end{abstract}

Substance-related disorders are the most common mental illnesses among burn patients [8]. The link between burn trauma and mental illness is complicated. As reviewed by Palmu et al., mental illness can predispose an individual to burn trauma, and burn trauma can predispose an individual to mental illness. Furthermore, mental illness can complicate burn care and rehabilitation.

The most common addictive substances detected in burn patients are methamphetamine and cocaine [9]. Synthetic cannabinoids are becoming popular in society at large, making this substance a rising concern.

Synthetic cannabinoids were developed as an alternative to cannabis for the diagnosis and treatment of diseases. Having become commercially available, these substances are now used for their relaxant and hallucinogenic effects. The most common name for synthetic cannabinoids in our country is Bonzai; other names include Black Mamba, K2, Spice, Scope, Smoke, Dream, and Jamaican Gold. Although the use of these synthetic substances is prohibited by law, they are widely available and cheap. They are mostly used through smoking. They can cause a variety of side effects, including effects on the central nervous system, cardiovascular and gastrointestinal systems, and acute renal failure. Their use has also been linked to deaths [10].

In this study, data from patients with burns related to the effects of the synthetic cannabinoid Bonzai are presented, and the literature is reviewed. 2.Materials and Methods

In this retrospective study, patients with burns related to synthetic cannabinoids who were referred to Plastic Surgery and Orthopedics Clinics between January 2018 and December 2020 were included. Demographic data, burn locations, total burn surface area (TBSA), operations, complications, and followup of the patients were recorded. Burn injury patients under the effects of drugs other than synthetic cannabinoids or whose drug use was unverified were excluded from the study.

All procedures performed in this study were in accordance with the ethical standards of the institutional research committee and with the 1964
Declaration of Helsinki and its later amendments or comparable ethical standards. All participants signed a written informed consent form.

\section{Results and Discussion}

3.1.Results

Between January 2018 and December 2020, a total of 12patients with burn injuries under the effect of synthetic cannabinoids were referred to plastic surgery and orthopedics clinics (Table 1). Three were female and nine were male, with an average age of 33.5 years (a range of 18-57 years of age). Eleven patients were injured due to falling into flames. The fires were built for warmth for outdoors. Most injuries were on the extremities (ten patients). TBSA ranged from $2 \%$ to $40 \%$. Eight patients had thirddegree burns, two had second-degree burns, and two had both second- and third-degree burns.

All patients were under the influence of synthetic cannabinoids when the burn injury occurred. On their history check, it was determined that four patients were alcoholics, one patient was a methamphetamine addict, and four patients were using cannabis routinely along with cannabinoids. None of the patients had additional comorbidities. All patients were referred to the psychiatry clinic, and their medical therapy for agitation and withdrawal symptoms was planned according to these consultations.

Five patients had been operated on due to burn injuries; all of these patients had complications and secondary surgeries. Two patients were lost after being admitted to the hospital, and two patients were lost during follow-up after discharge from the hospital. One patient had escaped from the hospital without permission. The average follow-up duration of the remaining seven patients was 22 months. On their follow-up, only one patient was verified to be clean from drugs, whereas two patients were imprisoned due to drug-related issues. The other patients' drug use could not be screened for during follow-up visits.

\subsection{Discussion}

Synthetic cannabinoids, which first became globally commercially available in the 2000sand were first detected in our country in the early 2010s, are emerging dangers for substance abuse [11]. Many types are available illegally on the market, making complications related to these substances highly variable $[10,12]$. Usage of synthetic cannabinoids is linked to addiction, withdrawal, and severe physical and mental health effects. Synthetic cannabinoids have a higher affinity for cannabinoid receptors than cannabis; therefore, they are more potent and toxic. They have serious complications such as psychosis, suicidal tendencies, and cardiac and pulmonary complications that can lead to death [12]. 
Table 1. Characteristics of the patients

\begin{tabular}{|c|c|c|c|c|c|c|c|c|c|c|c|}
\hline $\begin{array}{l}\text { Patient } \\
\text { Number }\end{array}$ & Age & Sex & Drug Use & $\begin{array}{l}\text { Cause of } \\
\text { Burn }\end{array}$ & TBSA & $\begin{array}{l}\text { Burn } \\
\text { Degree }\end{array}$ & $\begin{array}{l}\text { Injury } \\
\text { Location }\end{array}$ & Operation & Complication & Reoperation & Follow Up \\
\hline 1 & 51 & $\mathrm{M}$ & $\mathrm{SC}+$ Alcohol & $\begin{array}{l}\text { Fall into } \\
\text { flames }\end{array}$ & $\% 40$ & $3^{\text {rd }}$ & $\begin{array}{l}\text { Lower } \\
\text { extremities + } \\
\text { perineum }\end{array}$ & None & - & - & Exitus \\
\hline 2 & 28 & $\mathrm{M}$ & $\mathrm{SC}$ & $\begin{array}{l}\text { Fall into } \\
\text { flames }\end{array}$ & $\% 2$ & $3^{\text {rd }}$ & Knee & $\begin{array}{l}\text { Reverse } \\
\text { anterolateral thigh } \\
\text { flap }\end{array}$ & $\begin{array}{l}\text { Suicide attempt } \\
\text { Flap necrosis }\end{array}$ & $\begin{array}{l}\text { Perforator } \\
\text { artery flap }\end{array}$ & 38 months \\
\hline 3 & 18 & $\mathrm{M}$ & $\mathrm{SC}+\mathrm{C}$ & $\begin{array}{l}\text { Fall into } \\
\text { flames }\end{array}$ & $\% 15$ & $3^{\text {rd }}$ & $\begin{array}{l}\text { Thorax + upper } \\
\text { extremity }\end{array}$ & $\begin{array}{l}\text { Abdominal } \\
\text { interpolation flap } \\
+ \text { split thickness } \\
\text { skin graft }\end{array}$ & $\begin{array}{l}\text { Failed graft, } \\
\text { regrafting, } \\
\text { osteomyelitis in } \\
\text { elbow }\end{array}$ & $\begin{array}{l}\text { Split thickness } \\
\text { skin graft }\end{array}$ & $\begin{array}{l}38 \text { months, } \\
\text { followed as a } \\
\text { prisoner }\end{array}$ \\
\hline 4 & 25 & $\mathrm{M}$ & $\mathrm{SC}$ & $\begin{array}{l}\text { Fall into } \\
\text { flames }\end{array}$ & $\% 18$ & $3^{\text {rd }}$ & $\begin{array}{l}\text { Lower } \\
\text { extremities }\end{array}$ & $\begin{array}{l}\text { Bilateral below } \\
\text { knee amputation }\end{array}$ & $\begin{array}{l}\text { Necrosis on } \\
\text { amputation } \\
\text { stumps }\end{array}$ & $\begin{array}{l}\text { Bilateral } \\
\text { above knee } \\
\text { amputation }\end{array}$ & $\begin{array}{l}\text { Lost to follow } \\
\text { up }\end{array}$ \\
\hline 5 & 25 & $\mathrm{M}$ & $\mathrm{SC}+\mathrm{C}$ & $\begin{array}{l}\text { Fall into } \\
\text { flames }\end{array}$ & $\% 2$ & $3^{\text {rd }}$ & Lower extremity & None & - & - & $\begin{array}{l}\text { Escaped from } \\
\text { hospital }\end{array}$ \\
\hline 6 & 57 & $\mathrm{M}$ & $\mathrm{SC}+$ Alcohol & $\begin{array}{l}\text { Fall into } \\
\text { flames }\end{array}$ & $\% 10$ & $3^{\text {rd }}$ & Lower extremity & None & - & - & Exitus \\
\hline 7 & 26 & $\mathrm{~F}$ & $\mathrm{SC}+\mathrm{C}$ & $\begin{array}{l}\text { Fall into } \\
\text { flames }\end{array}$ & $\% 15$ & $2^{\text {nd }}$ and $3^{\text {rd }}$ & $\begin{array}{l}\text { Face }+ \text { neck }+ \\
\text { thorax }\end{array}$ & $\begin{array}{l}\text { Split thickness } \\
\text { skin graft }\end{array}$ & $\begin{array}{l}\text { Neck and perioral } \\
\text { skin contracture- } \\
\text { contacture release } \\
\text { with z plasties and } \\
\text { grafting }\end{array}$ & $\begin{array}{l}\text { Contracture } \\
\text { release with z- } \\
\text { plasties and } \\
\text { grafting }\end{array}$ & $\begin{array}{l}24 \text { months, } \\
\text { followed as a } \\
\text { prisoner }\end{array}$ \\
\hline 8 & 52 & $\mathrm{M}$ & $\mathrm{SC}+$ Alcohol & $\begin{array}{l}\text { Fall into } \\
\text { flames }\end{array}$ & $\% 23$ & $2^{\text {nd }}$ and $3^{\text {rd }}$ & $\begin{array}{l}\text { Face + hands }+ \\
\text { feet }\end{array}$ & - & - & - & 22 months \\
\hline 9 & 48 & $\mathrm{~F}$ & SC + Alcohol & Assault & $\% 40$ & $2^{\text {nd }}$ & $\begin{array}{l}\text { Face + hands + } \\
\text { feet }\end{array}$ & - & - & - & $\begin{array}{l}\text { Lost to follow } \\
\text { up }\end{array}$ \\
\hline 10 & 29 & $\mathrm{M}$ & $\mathrm{SC}+\mathrm{M}$ & $\begin{array}{l}\text { Fall into } \\
\text { flames }\end{array}$ & $\% 47$ & $2^{\text {nd }}$ & $\begin{array}{l}\text { Upper } \\
\text { extremities + } \\
\text { feet }\end{array}$ & - & - & - & 16 months \\
\hline 11 & 19 & $\mathrm{M}$ & SC & $\begin{array}{l}\text { Fall into } \\
\text { flames }\end{array}$ & $\% 25$ & $3^{\text {rd }}$ & $\begin{array}{l}\text { Face + upper } \\
\text { extremities }+ \\
\text { thorax }+ \text { feet }\end{array}$ & $\begin{array}{l}4^{\text {th }}, 5^{\text {th }} \text { finger, } 5^{\text {th }} \\
\text { toe amputation }+ \\
\text { split thickness } \\
\text { skin graft }\end{array}$ & $\begin{array}{l}\text { Severe wrist } \\
\text { contracture }\end{array}$ & $\begin{array}{l}\text { Contracture } \\
\text { release with } \\
\text { abdominal } \\
\text { interpolation } \\
\text { flap }\end{array}$ & 12 months \\
\hline 12 & 24 & $\mathrm{~F}$ & $\mathrm{SC}+\mathrm{C}$ & $\begin{array}{l}\text { Fall into } \\
\text { flames }\end{array}$ & $\% 30$ & $3^{\text {rd }}$ & $\begin{array}{l}\text { Thorax }+ \\
\text { abdomen }\end{array}$ & $\begin{array}{l}\text { Split thickness } \\
\text { skin graft }\end{array}$ & - & - & 6 months \\
\hline
\end{tabular}

F: Female / M: Male, SC: Synthetic, Cannabinoid-Bonzai / C: Cannabis-Marijuana / M: Methamphetamine, TBSA: Total Burn Surface Area 
The most common complications are tachycardia, lethargy, and agitation [10]; catatonia and seizures have also been reported. Lethargy, catatonia, and seizures were the main reasons for burns in our study All the patients except from one fell onto fire due to depressed motor and mental functions after synthetic cannabinoid use.In fact, these depressant effects are commonly reported by both the public and health care providers in our country, as these cannabinoid users are commonly found disoriented, disorganized, and drowsy in the streets [13].

Synthetic cannabinoids are reported to be used more frequently by males, adolescents, young adults, and those who use cannabis and other drugs [12]. In our study, the average age of the patients was 33.5 years (age range: 18-57). Although the patient number is too low to project to the general population, this high range is of concern due to the ready availability of the substance. The dominance of male patients and usage of other drugs in our study are consistent with the literature.

Burns related to different illegal drugs have been examined in the literature. Methamphetamine, cocaine, heroin, and cannabis are the most common illegally used drugs among burn patients [5, 9]. However, reports on burns related to synthetic cannabinoids are few. Only one Bonzai-related burn has been presented as a case study, by Basat et al. [14]. Like our patients, the patient had a long hospital stay and required serial operations. Another burn trauma related to synthetic cannabinoid Black Diamond was reported as a self-inflicted burn that resulted in bilateral upper extremity amputations [15].

Drug abuse increases the length of stay in the hospital, complications, and mortality in burn patients [1, 6, 7]. Graft loss, donor-site problems, and infection are more common in drug-intoxicated patients [6]. We did not do any statistical analyses to compare the burn patients due to the low number of cases in our study; however, all patients that required surgery had complications. In addition, two out of twelve patients were lost. The complications were increased in these patients, but further comparative studies are needed to confirm this observation.

Risky behaviors among drug users are common. Leung et al. showed that accelerant-related burns are more common in drug-abusing patients [16]. Accelerants may be used in the manufacture of illegal drugs or, as with our patients, they may be used to accelerate a fire outdoors. Patients with risky behavioral tendencies should be observed carefully in clinics, as they can harm themselves, other patients, or health care providers. One of our patients made a suicide attempt in the clinic, and one patient escaped from the clinic. Psychiatry consultations are critically important for these patients; furthermore, these patients should be closely monitored after discharge from the hospital. Drug-abusing patients have an increased risk of having acute mental disorders after burns [2].

Negative labeling and stigmatizing behavior toward individuals using addictive substances may also be factors causing increased risk of trauma. These social factors delay the acceptance and initiation of treatment for addiction, decrease the effectiveness of treatment, and make it difficult for the addicted individual to adapt to society. Studies have revealed that society considers people with substance-abuse issues to be dangerous to society, disrespectful, unable to make decisions, and to have higher potential to commit crimes [17]. These negative beliefs lead to the social exclusion of addicted people. In our study, nearly all patients were burned because of fires lit for warmth while they lived outdoors. Kaylı et al. revealed that negative attitudes toward addicted people decrease in societies with higher education levels [18]. Regular educational programs can help ensure that drug addicts are not ostracized. In this way, exposure to trauma for this population can be reduced, and these patients can benefit from health services without delay or obstacles.

\section{Sonuc}

Substance addiction not only has negative outcomes for individuals, but it is also a multifactorial public health problem. Addiction puts patients at greater risk for both trauma and burns. A preventative approach addressing socioeconomical, cultural, behavioral, and psychiatric issues would reduce the burden of burn injuries in those at greater risk.

\section{Acknowledgement and Disclosures \\ Conflict of Interest: Non \\ Funding: Non}

References

1.Haum, A, Perbix, W, Hack, H.J, Stark, G.B, Spilker, G, et al., Alcohol and drug abuse in burn injuries, Burns: journal of the International Society for Burn Injuries, 1995, 21, 194-199.

2.Mahendraraj, K, Durgan, D.M, Chamberlain R.S, Acute mental disorders and short and long term morbidity in patients with third degree flame burn: A population-based outcome study of 96,451 patients from the Nationwide Inpatient Sample (NIS) database (20012011), Burns: journal of the International Society for Burn Injuries, 2016, 42, 1766-1773.

3. McKibben, J.B, Ekselius, L, Girasek, D.C, Gould, N.F, Holzer, C, et al., Epidemiology of burn injuries II: psychiatric and behavioural perspectives, International review of psychiatry, 2009, 21, 512-521.

4.Danks, R.R, Wibbenmeyer, L.A, Faucher, L.D, Sihler, K.C, Kealey, G.P, et al., Methamphetamine-associated burn injuries: a retrospective analysis, The Journal of burn care \& rehabilitation, 2004, 25, 425-429.

5.Hodgman, E.I, Subramanian, M, Wolf, S.E, Arnoldo, B.D, Phelan, H.A, et al., The effect of illicit drug use on outcomes following burn injury, Journal of burn care \& research: official publication of the American Burn Association, 2017, 38, e89-e94.

6. Grobmyer, S.R, Maniscalco, S.P, Purdue, G.F, Hunt, J.L, Alcohol, drug intoxication, or both at the time of burn injury as a predictor of complications and mortality in hospitalized patients with burns, The Journal of burn care \& rehabilitation, 1996, 17, 532-539.

7. Thombs, B.D, Singh, V.A, Halonen, J, Diallo, A, Milner, S.M, The effects of preexisting medical comorbidities on mortality and length of hospital stay in acute burn injury: evidence from a national sample of 31, 338 adult patients, Annals of surgery, 2007, 245, 629-634.

8. Palmu, R, Suominen, K, Vuola, J, Isometsa, E, Mental disorders among acute burn patients, Burns: journal of the International Society for Burn Injuries, 2010, 36, 1072-1079.

9. Swenson, J.R, Dimsdale, J.E, Rockwell, E, Carroll, W, Hansbrough, J, Drug and alcohol abuse in patients with acute burn injuries, Psychosomatics, 1991, 32, 287-293.

10. Mills, B, Yepes, A, Nugent, K, Synthetic Cannabinoids, The American journal of the medical sciences, 2015, 350, 59-62. 
11. Gurdal, F, Asirdizer, M, Aker, R.G, Korkut S, Gocer Y, et al., Review of detection frequency and type of synthetic cannabinoids in herbal compounds analyzed by Istanbul Narcotic Department of the Council of Forensic Medicine, Turkey, Journal of forensic and legal medicine, 2013, 20, 667-672.

12. Grigg, J, Manning, V, Arunogiri, S, Lubman, D.I, Synthetic cannabinoid use disorder: an update for general psychiatrists, Australasian psychiatry: bulletin of Royal Australian and New Zealand College of Psychiatrists, 2019, 27, 279-283.

13. Aladag-Ciftdemir, N, Yucel, I, Duran, R, Vatansever-Ozbek, U, Acunas, B, A new emerging problem in pediatric emergency units: Synthetic cannabinoids, The Turkish journal of pediatrics, 2016, 58, 492-497.

14. Basat, S.O, Ceran, F, Kurt, M, Bozkurt, M, Is Alice in Wonderland? A new cause for burns due to "Bonzai abuse", Burns: journal of the International Society for Burn Injuries, 2016, 42, 230-231.

15. Meijer, K.A, Russo, R.R, Adhvaryu, D.V, Smoking synthetic marijuana leads to self-mutilation requiring bilateral amputations, Orthopedics, 2014, 37, e391-394.

16. Leung, L.T.F, Papp, A, Accelerant-related burns and drug abuse: Challenging combination, Burns: journal of the International Society for Burn Injuries, 2018, 44, 646-650.

17. Yılmaz, G, Kayl1, D.S, Atitudes and behaviors of the society towards individuals using addictivesubstance: Case of Manisa /Toplumun bağımlılık yapıcı madde kullanan bireylere yönelik tutum ve davranışları: Manisa ili örneği, Celal Bayar University Journal of Social Sciences, 2020, 18, 326-338.

18. Kaylı, D.Ş, Özyurt, B.C, Haum, A, Perbix, W, Hack H.J, Stark, G.B Spilker, G, et al., Alcohol and drug abuse in burn injuries, Burns: journal of the International Society for Burn Injuries, 1995, 21, 194

http://edergi.cbu.edu.tr/ojs/index.php/cbusbed isimli yazarın CBU-SBED başlıklı eseri bu Creative Commons Alınt1-Gayriticari4.0 Uluslararası Lisansı ile lisanslanmıştır.

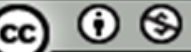

